\title{
Research on Evaluation and Optimization Methods of Power Grid Investment Projects Based on Effectiveness Contribution
}

\author{
Shiyan Mei ${ }^{1}$, Kai Hou ${ }^{1}$, Ming Chen ${ }^{1}$, Jinlan $\mathrm{Hu}{ }^{1}$, Chao Chen ${ }^{2 *}$ \\ ${ }^{1}$ Power Grid Planning \& Research Center, Guangdong Power Grid Co., Ltd., Guangzhou City, Guangdong, 510000, China \\ ${ }^{2}$ School of Economics and Management, North China Electric Power University, Beijing 102206, China
}

\begin{abstract}
Facing the current complex operation and management situation, power grid companies must improve the level of precision investment and improve the efficiency of project input and output. Based on the different goals of project investment, this paper uses comprehensive benefit evaluation methods to carry out micro-investment demand analysis from the project dimension, builds a quantitative evaluation index system for comprehensive benefits of power grid projects based on effectiveness contribution evaluation, and combines the analytic hierarchy process and entropy weight method to determine the index weights. Analyze the contribution degree of each project to the power grid after it is put into production through indicators, and realize the priority ranking of power grid investment projects according to the comprehensive benefit evaluation score of the project. The research results can provide reference and reference for improving the output efficiency of power grid investment projects.
\end{abstract}

\section{Introduction}

Affected by multiple factors such as the downturn in the macroeconomic situation, the growth rate of electricity, the narrowing of the space for transmission and distribution prices, and the policy-based price cuts, the power grid has a severe operating situation and faces many development problems. At the same time, in the face of the continuous deepening of power reform and the reform of state-owned enterprises, government supervision has become increasingly strict, and the profit model of power grid business and the mode of enterprise development have undergone profound changes. Under the new situation of the new round of power system reform and the new normal of economic development, how Realizing the grid input and output management and control goals that require efficiency and benefit has become a top priority. Therefore, in view of the increasing number of power grid investment projects, how to reasonably choose, clarify the construction sequence of power grid investment projects, determine the power grid investment strategy, and reduce the investment risks of various power grid projects are practical problems that need to be solved urgently.

Literature ${ }^{[1]}$ determined specific indicators according to the analytic hierarchy process, and designed a production project priority ranking model according to the weight of the indicators and the ideas and processes of model design. Literature ${ }^{[2]}$ constructs a comprehensive project evaluation index system from four aspects: urgency, importance, policy and feasibility, uses the analytic hierarchy process to give the recommended value of each indicator weight, and builds a comprehensive evaluation model for the ordering of power grid reserve projects. Items are scored. Literature ${ }^{[3]}$ examines the urgency of power grid project construction and the rationality of technical standards, and optimizes the sequence of project construction. Further economic evaluation of power grid construction projects, measuring the benefits of the project and performing a second order, through the comprehensive analysis of reliability and economic benefits, the optimal construction order of the project is obtained. Literature ${ }^{[4]}$ established a $110 \mathrm{kV}$ power grid project urgency evaluation index system based on the principle of analytic hierarchy process, based on the fuzzy membership method, determined the calculation method of the evaluation standard, and realized the comprehensive evaluation method of quantitative analysis of power grid project ranking.

To sum up, the current evaluation model is relatively single, and the scientificity of evaluation weight determination needs to be improved. This article combines the contribution degree to construct an evaluation index model from multiple dimensions, and adopts the subjective and objective weight determination method to ensure the scientificity of the weight determination results. The research results can improve the rationality of the ordering of power grid investment projects and enhance the scientificity of project decisionmaking.

*Corresponding author's e-mail: 1182306191@ncepu.edu.cn 


\section{Construction of the evaluation model for the contribution of power grid investment projects}

\subsection{Construction of evaluation index system}

At present, with the continuous advancement of China's transmission and distribution price reform, new requirements for project effectiveness and supervision have been put forward. There is an urgent need to improve the accuracy of project arrangements and select projects with relatively high comprehensive benefits. This article combines the actual situation to scientifically construct a preferred evaluation system based on the evaluation of project contribution. This paper relies on the existing research results, combined with the actual situation of the project selection decision, fully considers the purpose and benefit of power grid investment projects, and studies the factors that affect the selection of power grid projects around development strategy, technology, economy, development needs, policies, etc. From the perspective of the whole system, construct an evaluation model.

(1) Principle of representativeness Based on the current research findings, it is not that the more indicators are selected, the more accurate the model, but the relationship between various factors should be compared to find indicators that are sufficient to meet the ultimate goal. Therefore, it is necessary to combine the actual meaning of each indicator, and select a representative comprehensive indicator to reflect the differences and characteristics of different indicators.

(2) Dynamic principle The selection of indicators should be based on the change level of the indicators before and after the implementation of the project, to avoid the lack of scientificity caused by the simple evaluation of the state level, and through dynamic comparative analysis, scientifically and reasonably reflect the benefits of project implementation.

(3) The principle of applicability The construction of the evaluation index system should fully consider the principle of applicability, taking into account the basic requirements of comprehensive representativeness of indicators, data availability, and indicator comparability, so as to scientifically and effectively reflect the benefits and effects before and after the implementation of the project, and avoid excessive amplification of functional effects. Or one-sided selection of inappropriate indicators.

\section{(4) The principle of innovation}

Innovation refers to the influencing factors that were not considered by previous scholars and companies, and these influencing factors can appropriately reflect the company's current operation and future development, combined with different project implementation types and purposes, it is preferred that innovative indicators can be effectively combined The company's future development direction and development trend, through investment to achieve business development goals.

\subsection{Construction of evaluation index system}

This paper relies on the existing research results, combined with the actual situation of the project selection decision, fully considers the purpose and benefit of power grid investment projects, and studies the factors that affect the selection of power grid projects around development strategy, technology, economy, development needs, policies, etc. From the perspective of the whole system, construct an evaluation model.

Table 1. Investment scale indicator system of county power grid companies.

\begin{tabular}{|c|c|c|}
\hline $\begin{array}{c}\text { Serial } \\
\text { number }\end{array}$ & Indicator name & Unit \\
\hline 1 & $\mathrm{~N}-1$ pass rate increase & $\%$ \\
\hline 2 & Increased level of power outage risk & $\%$ \\
\hline 3 & Short-circuit current lift & $\%$ \\
\hline 4 & Power output power increase & $\begin{array}{l}\text { Ten thousand } \\
\text { kVA }\end{array}$ \\
\hline 5 & Active power loss increase & kVA/household \\
\hline 6 & Unit investment power & $\begin{array}{c}\mathrm{MW} / \mathrm{Ten} \\
\text { thousand yuan }\end{array}$ \\
\hline 7 & $\begin{array}{l}\text { Maximum load rate of power grid } \\
\text { project }\end{array}$ & $\begin{array}{l}\text { Ten thousand } \\
\text { kVA }\end{array}$ \\
\hline 8 & New energy access installed capacity & MW \\
\hline
\end{tabular}

\subsection{Evaluation model construction}

(1) Subjective weight calculation based on analytic hierarchy process and Delphi method

First, organize experts to construct a judgment matrix based on the quantitative indicator system of the contribution to the development of the power grid, and use the analytic hierarchy process to calculate the consistency of the judgment matrices. According to the data processing method of Delphi method, the subjective weighting is formed.

According to the importance scale theory, construct a pairwise comparison judgment matrix A:

$$
A=\left(a_{i j}\right)_{n \times n}(i, j=1,2, \cdots, n)
$$

Then normalize the judgment matrix A, the calculation formula is:

$$
\bar{a}_{i j}=a_{i j} / \sum_{k=1}^{n} a_{k j}(i, j=1,2, \cdots, n)
$$

The calculation formula for weight is:

$$
w_{i}=\bar{w}_{i} / \sum_{i=1}^{n} \bar{w}_{i}(i=1,2, \cdots, n)
$$

Finally, the consistency is judged. If the consistency test is passed, the result is valid. Fail to adjust the result.

(2) Objective weight calculation based on entropy weight method

Suppose that $n$ evaluation indicators are used to decide and evaluate $m$ candidates.

$x_{i k}$ : The estimated value of the evaluation index $i$ of the candidate option $k . x_{i}^{*}$ : the ideal value of the evaluation index $i$. The value of $x_{i}^{*}$ varies with the characteristics of evaluation indicators. For profitability 
indicators, the larger $x_{i}^{*}$ is, the better; for loss indicators (inverse indicators), the smaller $x_{i}^{*}$ is, the better (it can also be converted to a positive indicator first).

1) Define the proximity $D_{i k}$ of $x_{i k}$ to $x_{i}^{*}$ :

$$
D_{i k}= \begin{cases}\frac{x_{i k}}{x_{i}^{*}} & x_{i}^{*}=\max \left\{x_{i k}\right\} \\ \frac{x_{i k}}{x_{i}^{*}} & x_{i}^{*}=\min \left\{x_{i k}\right\}\end{cases}
$$

2) $D_{i k}$ normalization processing:

$$
d_{i k}=D_{i k} / \sqrt{\sum_{i=1}^{n} \sum_{k=1}^{m} D_{i k}^{2}}
$$

3) Overall entropy: using $n$ evaluation indicators to evaluate the entropy $E$ of $m$ candidate options:

$$
E=-\sum_{i=1}^{n} \sum_{k=1}^{m} d_{i k} \ln d_{i k}
$$

4) The overall entropy when the indicator has nothing to do with the plan:

If the relative importance of the evaluation index has nothing to do with the alternatives, the entropy is calculated by the following formula:

$$
E=-\sum_{i=1}^{n} d_{i k} \ln d_{i}
$$

Where:

$$
d_{i}=\sum_{k=1}^{n} d_{i k}
$$

5) Conditional entropy of evaluation index $i$.

$$
E_{i}=-\sum_{k=1}^{m} \frac{d_{i k}}{d_{i}} \ln \frac{d_{i k}}{d_{i}}
$$

It can be seen from the extreme value of entropy that $\frac{d_{i k}}{d_{i}}(k=1,2, \ldots, m)$, that is, $d_{i 1} \approx d_{i 2} \approx \ldots d_{i k}$, the closer to equal, the greater the conditional entropy, and the greater the uncertainty of the evaluation index for the evaluation and decision-making of the selected program.

6) By normalizing the above formula, the entropy value that characterizes the importance of the evaluation decision of the evaluation index $i$ is obtained.

$$
e\left(d_{i}\right)=-\frac{1}{1_{n} m} \sum_{k=1}^{m} \frac{d_{i k}}{d_{i}} 1_{n} \frac{d_{i k}}{d_{i}}
$$

(3) Calculation of evaluation results

Combining the determination of weights with the nondimensional and normalized results of the indicators, and the linear weighting method, the final index evaluation results of different indicators are determined. Based on the above analysis, the method of linear weighted summation is used to calculate the index.

Based on the above analysis, this article uses linear weighted summation method for comprehensive evaluation, namely:

$$
F_{i}=\sum_{j=1}^{m} w_{i j} x_{i j}
$$

Where: $w_{i j}(i=1,2, \ldots, n ; j=1,2, \ldots, m)$ is the weight

\begin{tabular}{|c|c|c|c|c|}
\hline $\begin{array}{l}\text { Project } \\
\text { name }\end{array}$ & Project type & $\begin{array}{c}\text { Total } \\
\text { investment } \\
\text { (100 million } \\
\text { yuan) }\end{array}$ & $\begin{array}{c}\text { New } \\
\text { capacity } \\
\text { (Ten } \\
\text { thousand } \\
\text { kVA) }\end{array}$ & $\begin{array}{l}\text { Line length } \\
\quad(\mathrm{km})\end{array}$ \\
\hline A & $\begin{array}{l}\text { Improve grid } \\
\text { safety }\end{array}$ & 37168 & & 135.8 \\
\hline B & $\begin{array}{l}\text { Meet the new } \\
\text { load }\end{array}$ & 1188 & 18 & \\
\hline $\mathrm{C}$ & Wind power & 62300 & & 170.65 \\
\hline D & $\begin{array}{l}\text { Improve grid } \\
\text { safety }\end{array}$ & 17383 & 48 & 38.8 \\
\hline E & $\begin{array}{l}\text { Meet the new } \\
\text { load }\end{array}$ & 11621 & 48 & 26.6 \\
\hline $\mathrm{F}$ & $\begin{array}{c}\text { Meet the new } \\
\text { load }\end{array}$ & 9721 & 48 & 19 \\
\hline G & $\begin{array}{l}\text { Improve grid } \\
\text { safety }\end{array}$ & 10212 & 48 & 1 \\
\hline $\mathrm{H}$ & $\begin{array}{l}\text { Meet the new } \\
\text { load }\end{array}$ & 6874 & 36 & 22 \\
\hline I & $\begin{array}{l}\text { Meet the new } \\
\text { load }\end{array}$ & 11176 & 48 & 16.6 \\
\hline $\mathrm{J}$ & $\begin{array}{l}\text { Strengthen the } \\
\text { grid structure }\end{array}$ & 8256 & & 20.6 \\
\hline
\end{tabular}
of the indicator, and $x_{i j}$ is the standardized data of the indicator.

\section{Empirical analysis}

This article selects $\mathrm{C}$ provincial power grid company as the object to carry out empirical analysis. The basic data collection situation is shown in the table below.

\begin{tabular}{|c|c|c|c|c|c|c|c|c|}
\hline $\begin{array}{c}\text { Proje } \\
\text { ct } \\
\text { name }\end{array}$ & $\begin{array}{c}\mathrm{N}-1 \\
\text { pass } \\
\text { rate } \\
\text { increa } \\
\text { se }\end{array}$ & $\begin{array}{c}\text { Increas } \\
\text { ed level } \\
\text { of } \\
\text { power } \\
\text { outage } \\
\text { risk }\end{array}$ & $\begin{array}{l}\text { Short- } \\
\text { circuit } \\
\text { curren } \\
\text { t lift }\end{array}$ & $\begin{array}{c}\text { Power } \\
\text { output } \\
\text { power } \\
\text { increas } \\
\text { e }\end{array}$ & $\begin{array}{c}\text { Active } \\
\text { power } \\
\text { loss } \\
\text { increa } \\
\text { se }\end{array}$ & $\begin{array}{l}\text { Unit } \\
\text { investme } \\
\text { nt power }\end{array}$ & $\begin{array}{c}\text { Maximu } \\
\mathrm{m} \text { load } \\
\text { rate of } \\
\text { power } \\
\text { grid } \\
\text { project }\end{array}$ & $\begin{array}{c}\text { New } \\
\text { energy } \\
\text { access } \\
\text { installe } \\
\text { d } \\
\text { capacit } \\
\text { y }\end{array}$ \\
\hline A & $\begin{array}{c}32.09 \\
\%\end{array}$ & $4.13 \%$ & $\begin{array}{c}14.04 \\
\%\end{array}$ & $0.00 \%$ & $\begin{array}{c}21.05 \\
\%\end{array}$ & $3.77 \%$ & $11.52 \%$ & $0.00 \%$ \\
\hline B & $0.00 \%$ & $0.00 \%$ & $\begin{array}{c}0.00 \\
\%\end{array}$ & $0.00 \%$ & $0.00 \%$ & $17.57 \%$ & $7.49 \%$ & $0.00 \%$ \\
\hline C & $0.00 \%$ & $35.73 \%$ & $\begin{array}{c}14.28 \\
\%\end{array}$ & $\begin{array}{c}100.00 \\
\%\end{array}$ & $1.75 \%$ & $1.26 \%$ & $13.08 \%$ & $\begin{array}{c}100.00 \\
\%\end{array}$ \\
\hline D & $\begin{array}{c}18.14 \\
\%\end{array}$ & $14.60 \%$ & $\begin{array}{c}10.84 \\
\%\end{array}$ & $0.00 \%$ & $\begin{array}{c}24.56 \\
\%\end{array}$ & $10.04 \%$ & $10.01 \%$ & $0.00 \%$ \\
\hline E & $0.93 \%$ & $15.06 \%$ & $\begin{array}{c}9.28 \\
\%\end{array}$ & $0.00 \%$ & $\begin{array}{c}15.79 \\
\%\end{array}$ & $7.53 \%$ & $5.64 \%$ & $0.00 \%$ \\
\hline F & $0.93 \%$ & $7.27 \%$ & $\begin{array}{c}7.98 \\
\%\end{array}$ & $0.00 \%$ & $3.51 \%$ & $12.97 \%$ & $7.41 \%$ & $0.00 \%$ \\
\hline G & $\begin{array}{c}17.67 \\
\%\end{array}$ & $8.67 \%$ & $\begin{array}{c}11.49 \\
\%\end{array}$ & $0.00 \%$ & $\begin{array}{c}15.79 \\
\%\end{array}$ & $8.37 \%$ & $11.46 \%$ & $0.00 \%$ \\
\hline H & $6.05 \%$ & $5.58 \%$ & $\begin{array}{c}11.49 \\
\%\end{array}$ & $0.00 \%$ & $8.77 \%$ & $12.97 \%$ & $10.04 \%$ & $0.00 \%$ \\
\hline I & $9.77 \%$ & $5.95 \%$ & $\begin{array}{c}10.48 \\
\%\end{array}$ & $0.00 \%$ & $7.02 \%$ & $7.95 \%$ & $8.19 \%$ & $0.00 \%$ \\
\hline $\mathrm{J}$ & $\begin{array}{c}14.42 \\
\%\end{array}$ & $3.01 \%$ & $\begin{array}{c}10.10 \\
\%\end{array}$ & $0.00 \%$ & $1.75 \%$ & $17.57 \%$ & $15.16 \%$ & $0.00 \%$ \\
\hline
\end{tabular}

Table 2. Basic data table.

Calculate the power grid data after the construction of each project in turn, and calculate the improvement and contribution of the power grid project evaluation index, as shown in the following table 3.

Table 3. Calculation results of indicator contribution.

Combine the subjective and objective weight calculation results to obtain the comprehensive weight, and combine the contribution calculation formula to obtain the final evaluation results of each project. 
Table 4. Evaluation result table.

\begin{tabular}{cc}
\hline Project name & Contribution \\
\hline A & 0.12 \\
B & 0.04 \\
C & 0.27 \\
D & 0.11 \\
E & 0.06 \\
F & 0.06 \\
G & 0.10 \\
H & 0.07 \\
I & 0.07 \\
J & 0.10 \\
\hline
\end{tabular}

\section{Conclusion}

This paper builds a project selection evaluation system based on contribution degree, from multiple perspectives, fully considers economic and social benefits, maximizes the effectiveness and accuracy of investment, and can provide support and guidance for accurate and scientific decision-making on power grid investment.

\section{References}

1. Shen Run. Research on the optimization and sorting model of power grid production projects based on analytic hierarchy process[J]. Communication Power Technology, 2019, 36(12): 24-25.

2. Zhao Juan, Yang Yang, Han Changzhan, Cui Kai. Comprehensive evaluation model for the sequencing of power grid reserve projects[J]. Shandong Electric Power Technology, 2018, 45(11): 37-41.

3. Li Canbing, Fu Meiping, Liang Jinzhao, Du Li. Optimized sequencing method for power grid construction projects based on evaluation of network coordination degree $[\mathrm{J}]$. Power System Protection and Control, 2010, 38(17): 112-115+120.

4. Zhao Juan, Yang Bo, Zhang Hongbin, Guo Yue. Research on urgency evaluation method of distribution network project based on analytic hierarchy process[J]. Electrical Technology, 2017(03): 64-68+72.

5. Song Tianqi, Ye Zuohong, Yao Zilin. The investment optimization strategy of power grid enterprises' technological transformation based on the weighted DEA model[J]. Microcomputer Application, 2021, 37(02): 161-162+172. 